\title{
Determination of antioxidant activity of yoghurt enriched with polymerized whey protein
}

\author{
Paulina Bierzuńska*, Dorota Cais-Sokolińska
}

\begin{abstract}
Poznań University of Life Sciences, Faculty of Food Science and Nutrition, Department of Dairy Products Quality, ul. Wojska Polskiego 31, 60-624 Poznań, Poland *Corresponding author/Dopisni autor: E-mail: paulina.bierzunska@up.poznan.pl
\end{abstract}

\section{Abstract}

The purpose of this study was to evaluate the antioxidant activity of yoghurt obtained from milk enriched with whey proteins in polymerized form. The influence of adding polymerized whey protein (PWP) on the antioxidant potential of yoghurt was demonstrated by determining the free radical content using 1,1-diphenyl-2-picrylhydrazyl (DPPH) and the ferric reducing antioxidant power (FRAP). The kinetics of coagulation was examined during fermentation at 37, 41 and 45 . The number of lactic acid bacteria was determined as well as their proteolytic and lipolytic activity. The results have shown that the addition of PWP accelerated the process of reaching the target $\mathrm{pH} 4.45$, thus reducing the fermentation time by as much as $21 \%$. PWP increased the antioxidant potential of yoghurt more than WPC80. The yoghurt obtained at $37^{\circ} \mathrm{C}$ had a higher antioxidant potential (DPPH $5.02 \mathrm{mmol} \cdot \mathrm{kg}^{-1}$; FRAP $5.52 \mathrm{mmol} \cdot \mathrm{L}^{-1}$ ) than those obtained at $41{ }^{\circ} \mathrm{C}$ and $43^{\circ} \mathrm{C}$. In the yoghurt with PWP, Lactobacillus were determined to have a concentration of $5.2 \times 109 \mathrm{CFU} \cdot \mathrm{mL}^{-1}$. After 21 days, the number of Streptococcus bacteria decreased. There was no effect of PWP on the number of Bifidobacterium bacteria.

\section{Key words: yoghurt, polymerized whey protein, antioxidant activity, lactic acid bacteria}

\section{Introduction}

Contemporary society is struggling with different diseases caused by the progress of civilization. These diseases tend to be either neoplastic or neurodegenerative in their nature. When fighting against them, it is helpful to eliminate free radicals from the body (Rajendran et al., 2014). An excessive number of free radicals can also damage cells and thereby halt cellular respiration (Giordano et al., 2013). Reactive oxygen species, including the superoxide radical, hydrogen peroxide, peroxide radical, and hydroxyl radical, are known to cause oxidative damage (Aloğlu and Öner, 2011). There are a number of artificial antioxidants that can pre- vent this, although the current consumer interest in healthy living has led to the search for natural alternative antioxidants, including rosmarinic acid, catechin, tocopherols, ascorbate, and various phenolic extracts from plants (Pownall et al., 2010). Antioxidants are found in selected spice oleoresins, such as cardamom, cinnamon, and nutmeg. Peptides and protein hydrolysates of plant and animal origin are also sometimes used (Xue et al., 2009).

It has been found that sulfur-containing amino acids, such as cystine, cysteine, and methionine, act as significant antioxidants in lipid systems (Smithers, 2008; Hwang and Winkler-Moser, 2017). Sulfur-containing amino acids can be found in soy proteins, whey proteins, chicken egg whites, and 
milk casein. The antioxidant effect of these peptides is primarily limited to chelating metal ions, capturing free radicals, and quenching singlet oxygen. Casein-released peptides inhibit lipoxygenase, which accelerates the peroxidation of unsaturated fatty acids, especially linoleic acid. The introduction of whey proteins constitutes an important step towards increasing the health value of fermented milk. Whey protein concentrates improve not only the structure-forming properties, but above all increase the antioxidant potential (Peńa-Ramos and Xiong, 2001). Whey proteins and whey alone, as a source of cysteine, favor the synthesis of glutathione, which is an intracellular antioxidant (Smithers, 2008). Whey proteins should be added to foods because of their therapeutic value. As a source of bioactive peptides, they have a beneficial physiological effect on the human body. They help relieve the nervous, cardiovascular, and immune systems, and they also have anticoagulant, antimicrobial, and antiviral properties (Smithers, 2008; Madureira et al., 2010). Some anti-cancer effects of whey proteins have also been demonstrated such as a diet rich in whey proteins significantly contributed to reducing the incidence of colonic cancer, as opposed to a diet rich in protein derived from, for example, meat or soybeans (Smithers, 2008). Whey proteins are currently used in traditional and new-generation foods as nutritive, physiologically active, and structurally-based ingredients, recognized, among other things, for their ability to create stable gels that give shape and texture to products, thereby improving their water absorption and preventing syneresis. These properties influence the overall acceptability of products subject to sensorial evaluation (Lammert et al., 2014).

The fermentation of milk contributes to the formation of peptides and free amino acids with various biological activities and antioxidant properties. This encourages the production of functional foodstuffs whose main ingredient is fermented milk (Sah et al., 2014). The fermentation of milk not only leads to prolongation of its stability, but also to the release of compounds, such as peptides, free amino acids, and fatty acids, with antioxidant properties (Gjorgievski et al., 2014). Gjorgievski et al. (2014) also demonstrated the effect on the antioxidant properties of fermented milk obtained by the use of various lactic acid bacteria (LAB), either as a monoculture or as symbiotic cultures. In addition, it was found that a probiotic culture of Lactobacillus acidophilus neutralized as much as $63.99 \%$ of 1,1-diphenyl-2-picrylhydrazyl (DPPH) radicals.

It is therefore believed possible to increase the antioxidant activity of yoghurt through the addition of whey protein, and to work out conditions for proper fermentation of processed milk. In recent years, there has been a significant increase in the popularity of yoghurt as a functional food (Granato et al., 2010; Illupapalayam et al., 2014). At the same time, yoghurt remains the most popular and preferred vehicle for probiotic culture (C ruz et al., 2012). The time and temperature parameters of fermentation can affect the numbers of the characteristic microflora and thus the antioxidant potential resulting from their metabolic activity. It is important that the product is not only healthier for the consumer, but also appealing in terms of the senses, which includes having good consistency and no syneresis. For this reason, the purpose of this study was to evaluate the antioxidant activity of yoghurt with probiotic microflora obtained from milk with added whey proteins, which were introduced in polymerized form.

\section{Materials and methods}

The raw material used was commercial pasteurized milk (OSM, Głubczyce, Poland) with a solid non-fat (SNF) content of $9.07 \%$ and $1.50 \%$ fat. In the experiment, three samples of yoghurt were made from this milk. These were: 1. From milk without additives. 2 . The dry matter (10.57\%) of the milk was increased to $16 \%$ by adding whey protein concentrate WPC80 (5.62 \% w/v). 3. The dry matter $(10.57 \%)$ of the milk was increased to $16 \%$ by adding polymerized whey protein (PWP) as a $28 \%$ solution (w/v); in a ratio of $0.23 \mathrm{~L}$ of solution for every 1 L of milk. The WPC80 (SM Spomlek, Radzyń Podlaski, Poland) contained $96.56 \%$ dry matter, including $79.43 \%$ proteins.

\section{Preparation of polymerized whey protein (PWP, $28 \%$, w/v)}

WPC80 whey protein concentrate powder (94.35 g) was dissolved in cold purified water (230 $\mathrm{mL}$ ) and held at $4{ }^{\circ} \mathrm{C}$ for $12 \mathrm{~h}$. The WPC dispersion was adjusted to $\mathrm{pH} 7.0$ with $0.1 \mathrm{M} \mathrm{NaOH}$ at $21^{\circ} \mathrm{C}$. 
It was heated at $85{ }^{\circ} \mathrm{C}$ for 30 min and was cooled rapidly to room temperature in ice-water with agitation.

\section{Production of yoghurt samples}

In the production of $\mathrm{t}$ yoghurts, the starter culture used was a mixture of thermophilic bacteria, Streptococcus thermophilus, Lactobacillus acidophilus, and Bifidobacterium animalis subsp. lactis, commercially available as Lyofast SAB 440B from Sacco (Cadorago, Italy), added at 10 units/25 L processed milk. Fermentation was performed at $37{ }^{\circ} \mathrm{C}$ until pH 4.45 was reached. A two-step cooling to $15{ }^{\circ} \mathrm{C}$ for a maximum of 15 min was applied, the product was poured into unit containers of $v=150 \mathrm{~mL}$, and further cooled to $6{ }^{\circ} \mathrm{C}$. Samples were produced on a pilot plant scale using factory-scale equipment $(n=8)$. They were tested $24 \mathrm{~h}$ after the completion of fermentation (day 0 ) and at 10 and 21 days of cold storage, i.e. at $3^{\circ} \mathrm{C} \pm 0.5^{\circ} \mathrm{C}$.

\section{Compositional analysis and physicochemical properties}

The content of total nitrogen (TN) was determined by the Kjeldahl method with the assistance of the Kjeltec System 1026 distilling unit (Tecator, Örebro, Sweden). The content of casein nitrogen $(\mathrm{CN})$, noncasein nitrogen (NCN), and nonprotein nitrogen (NPN) were determined according to Svanborg et al. (2015). The content of total protein (TP) and whey protein (WP) were calculated according to the following equations:

$$
\begin{aligned}
& \mathrm{TP}=(\mathrm{TN}-\mathrm{NPN}) \times 6.38 \\
& \mathrm{WP}=(\mathrm{NCN}-\mathrm{NPN}) \times 6.38
\end{aligned}
$$

where the number 6.38 represents the factor indicated for protein derived from milk.

The water activity was measured with an AquaLab Series 4TE instrument (Decagon Devices Inc., Pullman, USA) equipped with a thermostatic chamber controlled by means of the thermoelectric Peltier effect. The water activity, aw, was measured based on $\mathrm{pf}(\mathrm{T})$ - the value of the water vapor pressure for the sample when in a constant equilibrium during temperature $\mathrm{T}$ measurement, and $\mathrm{ps}(\mathrm{T})$ - the vapor pressure of saturated pure water at the same temperature $T$; these variables are related by the equation $a_{w}=p f(T) \times p s(T)^{-1}$. The accuracy of the measurement was \pm 0.003 aw and the measurement range was 0.03-1.000 aw. The measurements were carried out under conditions of thermodynamic equilibrium. The following solutions were used for calibration: $0.5 \mathrm{M} \mathrm{KCl}$ with $\mathrm{a}_{\mathrm{w}}=0.984\left(15^{\circ} \mathrm{C}\right)$, $6 \mathrm{M} \mathrm{NaCl}$ with $\mathrm{a}_{\mathrm{w}}=0.760\left(20^{\circ} \mathrm{C}\right), 8.57 \mathrm{M} \mathrm{LiCl}$ with $a_{w}=0.500\left(25^{\circ} \mathrm{C}\right)$, and $13.41 \mathrm{M} \mathrm{LiCl}$ with $\mathrm{a}_{w}=0.250$ $\left(25^{\circ} \mathrm{C}\right)$. Samples of $\mathrm{V}=15 \mathrm{~cm}^{3}$ were placed in a $\mathrm{DE}$ 501 measurement vessel (Decagon Devices Inc., Pullman, USA) and tested at $15^{\circ} \mathrm{C}$.

\section{Kinetics of coagulation}

The $\mathrm{pH}$ was measured using a $\mathrm{CP}-502 \mathrm{pH}-\mathrm{me}-$ ter (Elmetron, Zabrze, Poland) equipped with an ESAgP-301W combination electrode (Eurosensor, Gliwice, Poland) composed of glass and saturated silver chloride half-cells. The $\mathrm{pH}$ was automatically recorded at 15-min intervals. The maximum acidification rate $(\mathrm{Vm})$ was calculated from the $\mathrm{pH}$ curves according to the equation $\mathrm{Vm}=(\Delta \mathrm{pH} / \Delta \mathrm{t})$ and expressed in absolute values (unit $\mathrm{pH} / \mathrm{min}$ ). The maximum rate, $\mathrm{Vm}$, along with the time at which the maximum acidification rate was observed, Tm (min), and the time, Te (min), at which a pH of 4.45 was reached were the measured responses that characterized the fermentation kinetics (Kristo et al., 2003).

The titratable acidity values were expressed in Soxhlet-Henkel degrees ( ${ }^{\circ} \mathrm{SH}, 1^{\circ} \mathrm{SH}=0.0225$ lactic acid \%). A sample (25 mL) was pipetted into a 200 $\mathrm{mL}$ conical flask. The pipette was flushed with 25 $\mathrm{mL}$ water. The sample was titrated with standardized $0.25 \mathrm{~N} \mathrm{NaOH}$ using $1 \mathrm{~mL} 2 \%$ phenolphthalein as an indicator, giving an end-point of a faint pink color. The titration figure was multiplied by four to obtain the titratable acidity values.

\section{Lactic acid bacteria, proteolytic and lipolytic} activity

The isolation and determination of Lactobacillus lactic acid bacteria were performed on MRS, i.e. according to de Man, Rogosa, and Sharpe, agar substrate no. 110660 (Merck KgaA, Darmstadt, Germany) (Mainville et al., 2001). The substrate (68.2 g. $\left.\mathrm{L}^{-1}\right)$ had a $\mathrm{pH}$ of 5.7 at $25^{\circ} \mathrm{C}$ following dissolution and autoclaving ( $15 \mathrm{~min}$ at $121^{\circ} \mathrm{C}$ ). It was infected 
with the test material by the cast-iron method. The incubation was carried out at $37 \pm 1^{\circ} \mathrm{C}$ for $72 \mathrm{~h}$ under anaerobic conditions in a WTB Binder thermostat (Tuttlingen, Germany).

The isolation and determination of the number of Streptococcus lactic acid bacteria were performed on M-17 agar medium no. P-0220 (BTL, Łódź, Poland), as proposed by Terzaghi and Sandine for breeding and determining the number of lactic streptococci in milk and milk products (Gustaw et al., 2016). The substrate (57.3 g. $\left.\mathrm{L}^{-1}\right)$ had a pH of $7.0 \pm 0.2$ at $25^{\circ} \mathrm{C}$ following dissolution and autoclaving $\left(15 \mathrm{~min}\right.$ at $\left.121^{\circ} \mathrm{C}\right)$. It was infected with the test material by the cast-iron method. The incubation was carried out at $35 \pm 1^{\circ} \mathrm{C}$ for $24-48 \mathrm{~h}$ under anaerobic conditions in a WTB Binder thermostat (Tuttlingen, Germany).

An NPNL-MRS substrate was used to determine the number of Bifidobacterium probiotic bacteria. It was prepared using a combination of dicloxacillin, lithium chloride ( $\mathrm{LiCl}$ ), and cysteine hydrochloride (Cy$\mathrm{HCl}$ ). The Bifidobacterium viable cell counts were carried out by plating diluted yoghurt samples using the MRS agar with the addition of $0.5 \%$ of dicloxacillin stock solution, $1 \%$ of LiCl stock solution, and $0.5 \%$ of $\mathrm{CyHCl}$ stock solution per liter of medium. The plates were incubated for $48 \mathrm{~h}$ at $37^{\circ} \mathrm{C}$ under anaerobic conditions (Illupapalayam et al., 2014). The proteolytic and lipolytic activity of the microorganisms were noted as described by Guessas et al. (2012).

\section{Ferric reducing antioxidant power assay}

Ferric reducing antioxidant power (FRAP) evaluates the ability of the analyzed substance to reduce the complex of Fe(III)-2,4,6-tris(2-pirydyl)-striazine (TPTZ) to the form of Fe(II)-TPTZ (Benzie and Strain, 1996). The intensity of the blue colour, measured spectrophotometrically $(\lambda=583 \mathrm{~nm})$ using apparatus RayLeigh UV-1601 (Beijing Rayleigh Analitycal Instrument, Beijing, China) is linearly correlated with the reducing agent concentration. Results are presented as millimoles of $\mathrm{Fe}^{2+}$ per litre, based on a standard curve

$$
y=0.0001 x+0.0113 ; r^{2}=0.9938
$$

where y presents absorbance, $x$ standard (Fe II) or evaluated sample concentration and $r^{2}$ presents coefficient of determination.

\section{DPPH radical scavenging assay}

The ability of an antioxidant to scavenge stable 1,1-diphenyl-2-picrylhydrazyl (DPPH) radicals is evaluated spectrophotometrically $(\lambda=517 \mathrm{~nm})$ using RayLeigh UV-1601, in relation to the radical scavenging ability of the reference substance 6 -hydroxy-2,5,7,8-tetramethylchromane-2-carboxylic acid (Trolox) (Sánchez-Moreno et al., 1998). The absorbance decrease is a result of the substance's radical scavenging ability. Results are presented as millimoles of Trolox equivalents (TE) per kilogram, based on a standard curve:

$$
y=83.8 x ; r^{2}=0.9635
$$

where y presents percentage (\%) of reduced DPPH radical, $x$ stands for standard (Trolox) or evaluated sample concentration and $r^{2}$ presents coefficient of determination.

\section{Statistical analysis}

The obtained data are expressed as mean values $(\mathrm{n}=8)$ and the respective standard deviations (mean \pm SD) and analyzed by using repeated-measures ANOVA. Paired t-tests were used for the calculations. For the verification of statistical hypotheses, a level of significance at $a=0.05$ was adopted. The statistical calculations were made using the Statistica data analysis software system, version 10 (StatSoft, Tulsa, Oklahoma, USA).

\section{Results and discussion}

\section{Kinetics of fermentation}

The higher the temperature, the higher was the milk fermentation souring speed, Vm (Table 1; Fig. 1). The addition of WPC 80 accelerated the acidification at 37 and $41^{\circ} \mathrm{C}$ more than adding PWP $(P<0.05)$. The highest value of $V m$ was found in samples containing WPC80 and PWP incubated at $45^{\circ} \mathrm{C}(\mathrm{P}>0.05)$. The same samples quickly reached the required acidity ( $\mathrm{pH}$ 4.45). The more whey protein in the milk, the faster the $\mathrm{pH}$ was lowered during its fermentation, and thus the yoghurt reached the target $\mathrm{pH}$ of 4.45 sooner. The addition of milk to PWP reduced the milk fermentation time by 90 
$\min (21 \%)$. At $45{ }^{\circ} \mathrm{C}$, the addition of whey protein reduced the required fermentation time (to reach $\mathrm{pH} 4.45$ ) by $30 \mathrm{~min}$ (9\%). A similar direction of change was reported by Amatayakul et al. (2006), according to whom more whey protein in milk gives a simultaneous increase in nutrients that may have a significant effect on the growth of the starter culture, thereby shortening the fermentation time.

TABLE 1. Kinetic characteristics of fermentation

\begin{tabular}{l|l|l|l|l}
\hline Sample & Fermentation $\left({ }^{\circ} \mathrm{C}\right)$ & $\mathrm{V}_{\mathrm{m}}\left(\right.$ unit $\left.\mathrm{pH} \cdot \mathrm{min}^{-1}\right)$ & $\mathrm{T}_{\mathrm{m}}(\mathrm{min})$ & $\mathrm{T}_{\mathrm{e}}(\mathrm{min})$ \\
\hline \multirow{3}{*}{ control } & 37 & $0.0061^{\mathrm{a}}$ & $270^{c}$ & $435^{\mathrm{d}}$ \\
\cline { 2 - 5 } & 41 & $0.0065^{\mathrm{b}}$ & $270^{c}$ & $375^{\mathrm{c}}$ \\
\cline { 2 - 5 } & 45 & $0.0072^{\mathrm{c}}$ & $225^{\mathrm{b}}$ & $330^{\mathrm{b}}$ \\
\hline \multirow{3}{*}{ with WPC80 } & 37 & $0.0072^{\mathrm{c}}$ & $210^{\mathrm{b}}$ & $345^{\mathrm{b}}$ \\
\cline { 2 - 5 } & 41 & $0.0087^{\mathrm{d}}$ & $150^{\mathrm{a}}$ & $315^{\mathrm{a}}$ \\
\cline { 2 - 5 } & 45 & $0.0092^{\mathrm{e}}$ & $150^{\mathrm{a}}$ & $300^{\mathrm{a}}$ \\
\hline \multirow{3}{*}{ with PWP } & 37 & $0.0067^{\mathrm{b}}$ & $210^{\mathrm{b}}$ & $345^{\mathrm{b}}$ \\
\cline { 2 - 5 } & 41 & $0.0078^{\mathrm{d}}$ & $210^{\mathrm{b}}$ & $315^{\mathrm{a}}$ \\
\cline { 2 - 5 } & 45 & $0.0091^{\mathrm{e}}$ & $150^{\mathrm{a}}$ & $300^{\mathrm{a}}$ \\
\hline
\end{tabular}

$V m$, maximum acidification rate; $T_{m}$, time at which; $V_{m}$ is reached; $T_{e}$, time to reach $\mathrm{pH}$ 4.45. Different small letters in superscript in columns indicate statistically significant differences at the level $\mathrm{a}=\stackrel{0}{\mathrm{e}^{\prime}} .05$

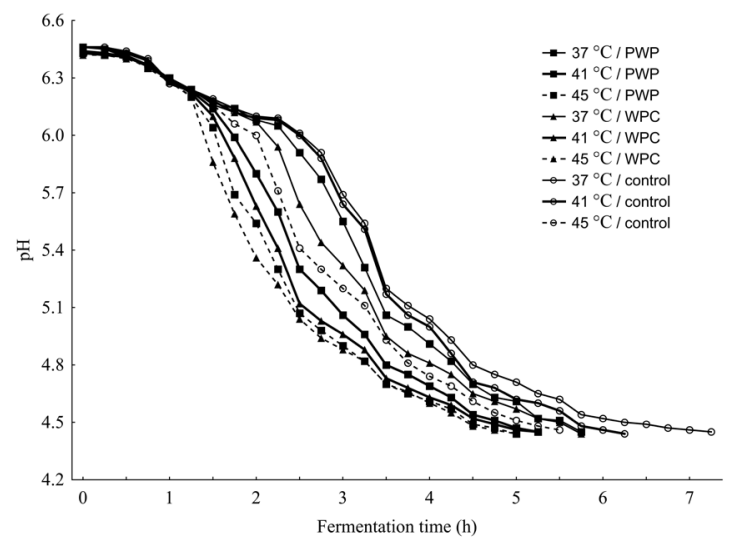

FIGURE 1. Reduction in pH of yoghurts made using WPC80 and PWP with different temperatures of coagulation

TABLE 2. Composition and physicochemical characteristics of yoghurt with polymerized whey protein

\begin{tabular}{l|l|l|l}
\hline Parameters & control & with WPC80 & with PWP \\
\hline Solid non-fat $(\mathrm{g} / \mathrm{kg})$ & $90.7 \pm 0.4^{\mathrm{a}}$ & $160.1 \pm 0.1^{\mathrm{b}}$ & $160.0 \pm 0.2^{\mathrm{b}}$ \\
\hline $\mathrm{TN}(\mathrm{g} / \mathrm{kg})$ & $5.61 \pm 0.04^{\mathrm{a}}$ & $12.83 \pm 0.02^{\mathrm{b}}$ & $12.91 \pm 0.01^{\mathrm{b}}$ \\
\hline $\mathrm{NPN}(\mathrm{g} / \mathrm{kg})$ & $0.34 \pm 0.04^{\mathrm{a}}$ & $0.31 \pm 0.03^{\mathrm{a}}$ & $0.33 \pm 0.01^{\mathrm{a}}$ \\
\hline $\mathrm{NCN}(\mathrm{g} / \mathrm{kg})$ & $1.22 \pm 0.06^{\mathrm{a}}$ & $8.26 \pm 0.01^{\mathrm{b}}$ & $8.14 \pm 0.03^{\mathrm{b}}$ \\
\hline $\mathrm{TP}(\mathrm{g} / \mathrm{kg})$ & $33.47 \pm 0.01^{\mathrm{a}}$ & $79.9 \pm 0.02^{\mathrm{b}}$ & $79.8 \pm 0.04^{\mathrm{b}}$ \\
\hline $\mathrm{C}(\mathrm{g} / \mathrm{kg})$ & $26.85 \pm 0.02^{\mathrm{a}}$ & $27.17 \pm 0.06^{\mathrm{a}}$ & $26.92 \pm 0.02^{\mathrm{a}}$ \\
\hline WP $(\mathrm{g} / \mathrm{kg})$ & $5.60 \pm 0.01^{\mathrm{a}}$ & $8.57 \pm 0.05^{\mathrm{b}}$ & $8.48 \pm 0.07^{\mathrm{b}}$ \\
\hline Fat $(\mathrm{g} / \mathrm{kg})$ & $15.2 \pm 0.1^{\mathrm{a}}$ & $15.1 \pm 0.2^{\mathrm{a}}$ & $15.0 \pm 0.1^{\mathrm{a}}$ \\
\hline Titratable acidity & $0.873 \pm 0.007^{\mathrm{b}}$ & $0.857 \pm 0.002^{\mathrm{a}}$ & $0.852 \pm 0.008^{\mathrm{a}}$ \\
\hline Proteolytic activity & no activity & no activity & no activity \\
\hline Lipolytic activity & no activity & no activity & no activity \\
\hline Water activity $(-)$ & $0.9780 \pm 0.0004^{\mathrm{a}}$ & $0.9769 \pm 0.0007^{\mathrm{a}}$ & $0.9781 \pm 0.0009^{\mathrm{a}}$ \\
\hline Vat & &
\end{tabular}

Values represent mean \pm standard deviation $(n=8)$. TN, total nitrogen; NPN, nonprotein nitrogen; NCN, noncasein nitrogen; TP, total protein $($ TN-NPN) $\times 6.38$; C, casein $($ TN-NCN-NPN) $\times 6.38$; WP, whey protein $(\mathrm{NCN}-\mathrm{NPN}) \times 6.38$. Titratable acidity is expressed as percentage of lactic acid. Proteolytic activity used Plate Count Agar with $1 \%$ and $2 \%(\mathrm{w} / \mathrm{v})$ skim milk - slight reaction with $1 \%$ and no activity was observed with $2 \%$. Different small letters in superscript in rows indicate statistically significant differences at the level $a=0.05$. 
According to the assumptions of the experiment, after the introduction of whey proteins into the milk, it increased its solid non-fat from 9 to $16 \%$ (Table 2). The whey protein content increased 1.5 -times $(\mathrm{P}<0.05)$. There was no great difference in the content of casein among the samples, all having values close to the average of $26.98 \mathrm{~g} \cdot \mathrm{kg}^{-1}$. Yoghurts with WPC80 and PWP had a lower titratable acidity than the control sample $(P<0.05)$. The water activity of all three yoghurt samples (control, with WPC80 and with PWP) was similar ( $>>0.05)$. All tested samples of yoghurt did not show proteolytic and lipolytic activity.

\section{Lactic acid bacteria}

After the fermentation at $41^{\circ} \mathrm{C}$ and $45^{\circ} \mathrm{C}$, the Lactobacillus bacteria in the yoghurts were found to be, on average, $5.1 \times 107 \mathrm{CFU} \cdot \mathrm{mL}^{-1}(\mathrm{P}>0.05)$. Only in the yoghurt obtained at $37^{\circ} \mathrm{C}$ were the number of Lactobacillus increased with the addition of whey proteins (with WPC80 $2.7 \times 108 \mathrm{CFU} \cdot \mathrm{mL}^{-1}$ and with PWP $5.2 \times 109 \mathrm{CFU} \cdot \mathrm{mL}^{-1}$ ) (Fig. 2). WPC80 and PWP had no effect on the number of Streptococcus bacteria $(P>0.05)$. In the yoghurt obtained at $45^{\circ} \mathrm{C}$, there were significantly more $(5.1 \times 108$ $\mathrm{CFU} \cdot \mathrm{mL}^{-1}$ ) Streptococcus bacteria than at $37^{\circ} \mathrm{C}$ and $41{ }^{\circ} \mathrm{C}$ (mean $6.0 \times 107 \mathrm{CFU} \cdot \mathrm{mL}^{-1}$ ) (Fig. 3). There was no effect of WPC80 and PWP on the number of Bifidobacterium bacteria. There were more present in the yoghurt obtained at $37^{\circ} \mathrm{C}(2.6 \times 107$ $\mathrm{CFU} \cdot \mathrm{mL}^{-1}$ ) than at $41^{\circ} \mathrm{C}$ and $45^{\circ} \mathrm{C}$ (mean $6.1 \times 106$ (FU.mL $\mathrm{mL}^{-1}$ ) (Fig. 4).

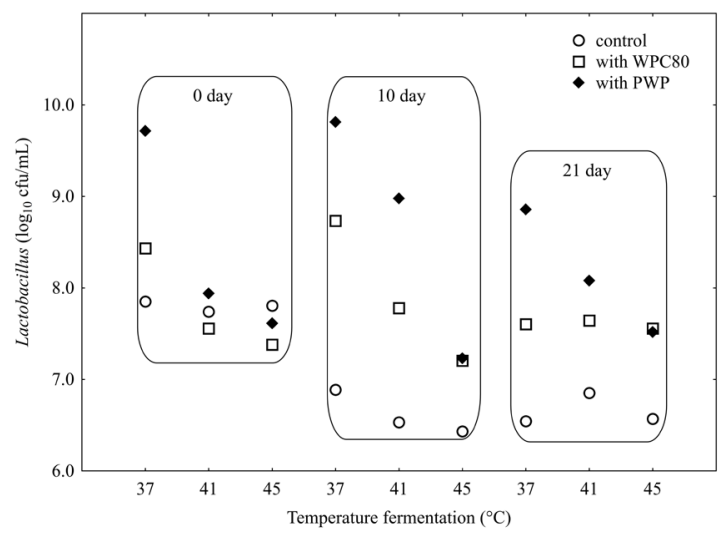

FIGURE 2. Number of Lactobacillus bacteria in stored yoghurt depending on fermentation temperature and whey protein supplement

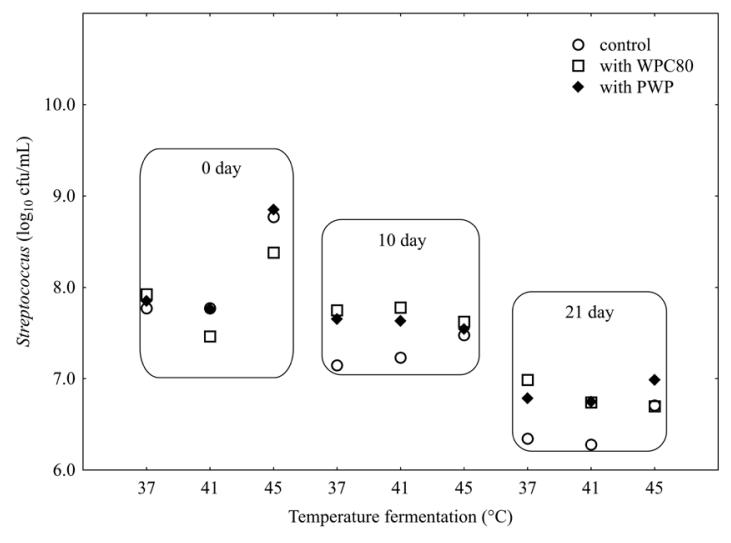

FIGURE 3. Number of Streptococcus bacteria in stored yoghurt depending on fermentation temperature and whey protein supplement

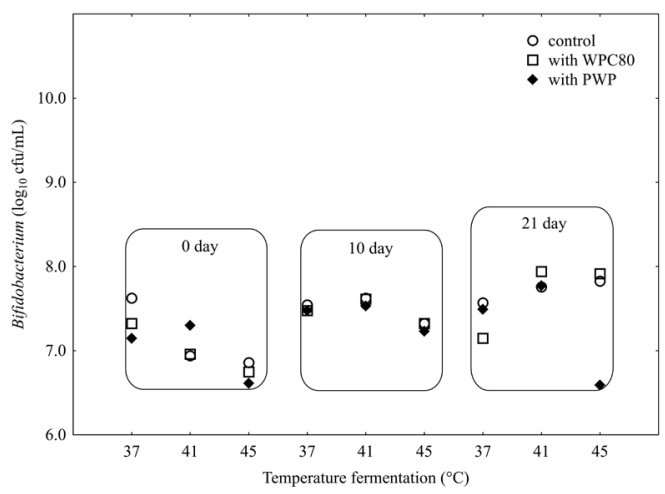

FIGURE 4. Number of Bifidobacterium bacteria in stored yoghurt depending on fermentation temperature and whey protein supplement

It was demonstrated that the addition of WPC80 and PWP influences the maintenance of the initial number of Lactobacillus bacteria in yoghurt during storage for 21 days. This relation was not shown when measuring Streptococcus and Bifidobacterium bacteria in stored yoghurts. The number of Streptococcus bacteria in the yoghurt decreased over time. After 10 days, it was $7.5 \mathrm{log}$ $\mathrm{CFU} \cdot \mathrm{mL}^{-1}$. After 10 days of storage, the number of Streptococcus bacteria was not affected by fermentation temperature (Fig. 3). After 21 days, the number of Streptococcus bacteria decreased to $6.7 \log \mathrm{CFU} \cdot \mathrm{mL}^{-1}$. Irrespective of the fermentation temperature and the composition of the processed milk, the number of Bifidobacteria in the yoghurt during storage remained unchanged (P>0.05) (Fig. 4). Wang et al. (2012) also analyzed yoghurt with polymerized whey proteins, examining 
its chemical composition and the possible changes that could occur during refrigerated storage. They analyzed the abundance of mold and yeast, the survival of the probiotic culture, $\mathrm{pH}$ changes, and the titratable acidity. The titratable acidity increased from $0.86 \%$ to $0.90 \%$ and from $0.83 \%$ to 0.91
$\%$ for yoghurt derived from goat's and cow's milk, respectively. Cultures of Lactobacillus casei and Bifidobacterium animalis subsp. lactis exhibited a lifetime concentration of more than $106 \mathrm{CFU} \cdot \mathrm{g}^{-1}$ over a twelve-week refrigerated storage period, although this was not the case with Lacobacillus acidophilus.

TABLE 3. Antioxidant activity of yoghurt made with WPC and polymer during fermentation at various temperatures and during further storage

\begin{tabular}{|c|c|c|c|c|c|c|c|}
\hline \multirow{3}{*}{ Yoghurt } & \multirow{3}{*}{$\begin{array}{l}\text { Fermentation } \\
\left({ }^{\circ} \mathrm{C}\right)\end{array}$} & \multicolumn{3}{|c|}{ DPPH $\left(\mathrm{mmol}^{\prime} \mathrm{kg}^{-1}\right)$} & \multicolumn{3}{|c|}{$\operatorname{FRAP}\left(\mathrm{mmol} \cdot \mathrm{L}^{-1}\right)$} \\
\hline & & \multicolumn{6}{|c|}{ Storage (d) } \\
\hline & & 0 & 10 & 21 & 0 & 10 & 21 \\
\hline \multirow[t]{3}{*}{ control } & 37 & $3.95^{\mathrm{BC}}$ & $2.48^{\mathrm{Bb}}$ & $2.23^{\mathrm{Ba}}$ & $4.06^{A c}$ & $2.74^{\mathrm{Bb}}$ & $2.59^{\mathrm{Ba}}$ \\
\hline & 41 & $3.80^{\mathrm{BC}}$ & $2.03^{\mathrm{Ab}}$ & $1.56^{\mathrm{Aa}}$ & $3.87^{A C}$ & $2.46^{\mathrm{Bb}}$ & $1.64^{\mathrm{Aa}}$ \\
\hline & 45 & $3.42^{A c}$ & $2.07^{\mathrm{Ab}}$ & $1.79^{\mathrm{Aa}}$ & $4.07^{A c}$ & $1.89^{\mathrm{Aa}}$ & $2.23^{\mathrm{Bb}}$ \\
\hline \multirow{3}{*}{$\begin{array}{l}\text { with } \\
\text { WPC80 }\end{array}$} & 37 & $4.89^{\mathrm{Ba}}$ & $4.81^{\mathrm{Ca}}$ & $4.17^{\mathrm{Ca}}$ & $5.03^{\mathrm{Bb}}$ & $4.97^{\mathrm{cb}}$ & $4.01^{\mathrm{Ba}}$ \\
\hline & 41 & $3.89^{\mathrm{Aa}}$ & $3.77^{\mathrm{Ba}}$ & $3.52^{\mathrm{Ba}}$ & $3.95^{\mathrm{Aa}}$ & $4.09^{\mathrm{Ba}}$ & $4.02^{\mathrm{Ba}}$ \\
\hline & 45 & $3.50^{\mathrm{Ab}}$ & $2.45^{\mathrm{Aa}}$ & $2.33^{\mathrm{Aa}}$ & $3.89^{\mathrm{Ab}}$ & $3.67^{\mathrm{Ab}}$ & $3.17^{\mathrm{Aa}}$ \\
\hline \multirow[t]{3}{*}{ with PWP } & 37 & $5.02^{\mathrm{Cb}}$ & $5.10^{\mathrm{Cb}}$ & $4.77^{\mathrm{Ca}}$ & $5.52^{\mathrm{Bb}}$ & $5.64^{\mathrm{cb}}$ & $5.01^{\mathrm{Ca}}$ \\
\hline & 41 & $4.01^{\mathrm{Ba}}$ & $4.12^{\mathrm{Ba}}$ & $3.87^{\mathrm{Ba}}$ & $4.28^{\mathrm{Ab}}$ & $4.55^{\mathrm{Bb}}$ & $4.07^{\mathrm{Ba}}$ \\
\hline & 45 & $3.68^{\mathrm{Ab}}$ & $2.99^{\mathrm{Aa}}$ & $2.97^{\mathrm{Aa}}$ & $4.25^{A c}$ & $3.87^{\mathrm{Ab}}$ & $3.14^{\mathrm{Aa}}$ \\
\hline
\end{tabular}

WPC, whey protein concentrate; PWP, polymerized whey protein; FRAP, ferric reducing antioxidant power expressed as millimoles of Fe2+; DPPH, antiradical power expressed as millimoles of Trolox equivalents. Values represent mean \pm standard deviation ( $\mathrm{n}=8$ ). Different large letters in superscript in columns indicate statistically significant differences at the level a=0.05 for the same type of additive. Different small letters in superscript in rows indicate statistically significant differences at the level $a=0.05$ for the same parameter.

\section{Antioxidant activity}

Our experiments showed that the antioxidant potential of yoghurt was influenced by the type of additive used (WPC80 or PWP) and the temperature and conditions of fermentation (Table 3). Increasing the proportion of whey proteins in yoghurt increased its antioxidant potential. The addition of PWP had a greater effect on the increase in DPPH and FRAP values than adding WPC80 (P<0.05). Immediately after the completion of the fermentation, the yoghurt with the most antioxidant effect was that with PWP obtained at $37{ }^{\circ} \mathrm{C}$ (DPPH 5.02 $\mathrm{mmol} / \mathrm{kg}$ ). This value was higher by $27 \%$ than the control yoghurt and about $3 \%$ higher than that of yoghurt with WPC80 $(P<0.05)$. The FRAP content in yoghurt with PWP obtained at $37{ }^{\circ} \mathrm{C}$ was also the highest of all the post-fermented ones (5.52 $\mathrm{mmol} / \mathrm{L}$ ) (Table 3). Yoghurts with PWP obtained at $41{ }^{\circ} \mathrm{C}$ and $45^{\circ} \mathrm{C}$ had a $23 \%$ lower FRAP value $(\mathrm{P}<0.05)$. In this way, it was demonstrated that the higher the fermentation temperature, the lower the DPPH and FRAP values.

Decreasing values of the antioxidant potential value were also observed with extended refrigeration storage times. After 21 days, the control yoghurt's DPPH value went down by an amount varying from $43.5 \%$ (yoghurt obtained at $37^{\circ} \mathrm{C}$ ) to $58.9 \%$ (at $41^{\circ} \mathrm{C}$ ). Yoghurt with WPC80 had a lower DPPH value after 21 days, with decreases varying from $14.7 \%\left(37^{\circ} \mathrm{C}\right)$ to $33.4 \%\left(45^{\circ} \mathrm{C}\right)$. Only the DPPH value in yoghurt with PWP obtained at $41^{\circ} \mathrm{C}$ remained unchanged $(P>0.05)$. In the case of samples with PWP obtained at other temperatures, the DPPH value decreased by $5 \%\left(37^{\circ} \mathrm{C}\right)$ and $19.3 \%$ $\left(45^{\circ} \mathrm{C}\right)$. Similar relations were shown by studying the FRAP values (Table 3). Wang et al. (2012) also demonstrated the beneficial effect of polymerized 
whey protein on the quality of yoghurt. They demonstrated that the addition of $0.4 \%$ of polymerized protein and $0.3 \%$ pectin to the yoghurt improves consistency and reduces syneresis. Wang et al. (2012) also found that polymerized whey protein could be a good thickening agent to improve yoghurt consistency. A similar trend was observed by Gustaw (2007) when investigating the effect of the addition of whey protein aggregates on yoghurt texture parameters. Whey protein aggregates obtained by single and double heating in Gustaw (2007) study had a significant effect on the rheological properties of the fermented milk obtained. The author showed that whey protein aggregates obtained as a result of single heating had a more favorable effect on the rheological properties of yoghurt than those obtained by double heating. He also proved that a yoghurt's hardness increased with the prolongation of whey protein aggregation, finding that the hardness of yoghurt with $1 \%$ added whey protein aggregates obtained by double heating was $110 \mathrm{~g}$, while that of yoghurt with $1 \%$ added whey protein aggregates obtained by single heating was $120 \mathrm{~g}$.

Our experiments showed that the greatest influence on the antioxidant potential expressed as DPPH and FRAP was caused by Lactobacillus bacteria. The calculated correlation coefficients and linearity coefficients of the linear functions are evidence for this $(r=0.806, y=1.042 x-4.622$ for $\mathrm{DPPH}$, and $r=0.830, y=1.056 x-4.360$ for FRAP). Such strong correlations were not demonstrated between the DPPH value and the number of Bifidobacterium ( $r=0.051)$ and Streptococcus $(r=0.187)$ bacteria. A very poor correlation ( $r=0.048, r=0.237$, respectively) was also demonstrated when studying FRAP. A similar direction of change using the DPPH radical was noted by Gjorgievski et al. (2014), who investigated the effect of starter cultures on the antioxidant properties of fermented milk. They made a comparison of the symbiotic culture of Lactobacillus delbruecki subsp. bulgaricus and Streptococcus thermophilus, as well as monocultures of Lacobacillus acidophilus, Lacobacillus casei, and Bifidobacterium animalis subsp. lactis. All the starter cultures used in the experiment by Gjorgievski et al. (2014) demonstrated a strong effect with regard to increasing the antioxidant activity of fermented milk compared to untreated milk. It was found that fermented milk containing Lacobacillus acidophilus neutralized up to $63.99 \%$ of free DPPH radicals. Fermented milk with a symbiotic culture of Lactobacillus delbruecki subsp. bulgaricus and Streptococcus thermophilus, meanwhile, neutralized up to $52.44 \%$ of DPPH free radicals after fermentation and 39.43 $\%$ on the third day of refrigerated storage. Sah et al. (2014), who relied for the production of yoghurt on Streptococcus thermophilus, Lactobacillus delbruecki subsp. bulgaricus as a control sample, and Streptococcus thermophilus, Lactobacillus delbruecki subsp. bulgaricus, Lactobacillus acidophilus, Lactobacillus casei, and Lactobacillus paracasei subsp. paracasei in various combinations, thus obtaining seven different samples, also confirmed its antioxidant properties. The authors measured the antioxidant potential spectrophotometrically, using the DPPH radical and additional 2,2'-azino-bis (3-ethylbenzothiazoline-6-sulfonic acid (ABTS). The antioxidant potential of the DPPH and ABTS radicals were expressed by the authors in terms of IC50, which is the concentration of peptides needed to inhibit $50 \%$ of the radicals. The highest antioxidant potential was found in yoghurt containing all three probiotic strains, i.e. Lactobacillus acidophilus, Lactobacillus casei, and Lactobacillus paracasei subsp. paracasei. The IC50 for this yoghurt was 1.51 $\mathrm{mg} \cdot \mathrm{mL}^{-1}$, as opposed to the control sample with an IC50 of $2.23 \mathrm{mg} \cdot \mathrm{mL}^{-1}$. The authors compared the IC50 of the yoghurt containing all three probiotic strains with ascorbic acid, the IC50 of which was $0.191 \mathrm{mg} \cdot \mathrm{mL}^{-1}$. A similar tendency was noted for the method involving the ABTS radical, which they also expressed in terms of IC50.

\section{Conclusions}

The study showed that it is possible to include polymerized whey protein in yoghurt. There were no differences in the kinetics of fermented milk with added whey protein concentrate in its native form and in its polymerized form. Whey protein supplementation increased the fermentation speed and shortened the time taken to reach the target $\mathrm{pH}$ of 4.45 by as much as $21 \%$. The addition of WPC 80 and PWP had a significant effect on the retention of the initial number of Lactobacillus bacteria during the 21-day storage refrigeration period. PWP increased the antioxidant potential of yoghurt more than WPC80. The most potent antioxidant poten- 
tial was that of the yoghurt with PWP obtained at $37^{\circ} \mathrm{C}$, which was $27 \%$ more than that of the control yoghurt and $3 \%$ more than yoghurt with WPC80. However, during storage, the most stable value of DPPH was that of the yoghurt with PWP obtained at $41^{\circ} \mathrm{C}$.

\section{Conflict of interest}

The authors declare that there are no conflicts of interest.

\section{Acknowledgements}

This study was financed by the Polish Ministry of Science and Higher Education MNSW-UPP grant no. 507.784.10.

\section{Određivanje antioksidacijske aktivnosti jogurta obogaćenog polimeriziranim proteinima sirutke}

\section{Sažetak}

Svrha ovog rada je odrediti antioksidacijsku aktivnost jogurta obogaćenog dodatkom polimeriziranih proteina sirutke. Utjecaj dodatka polimeriziranih proteina sirutke (PWP) na antioksidacijsku aktivnost jogurta ispitan je određivanjem koncentracije slobodnih radikala pomoću DPPH i FRAP metode. Kinetika koagulacije mlijeka ispitivana je na temperaturama fermentacije od 37,41 i $45^{\circ} \mathrm{C}$. Određivan je broj živih stanica bakterija mliječne kiseline te njihova proteolitička i lipolitička aktivnost. Prema dobivenim rezultatima vrijeme potrebno za postizanje ciljane pH vrijednosti od 4,45 skraćeno je za $21 \%$ dodatkom PWP. Osim toga, dodatak PWP u većoj mjeri povisio je antioksidacijsku aktivnost jogurta nego dodatak WPC80. Jogurt proizveden na $37^{\circ} \mathrm{C}$ imao je veću antioksidacijsku aktivnost (DPPH $5.02 \mathrm{mmol} \cdot \mathrm{kg}^{-1}$; FRAP $\left.5.52 \mathrm{mmol} \cdot \mathrm{L}^{-1}\right)$ u usporedbi s jogurtima proizvedenim na $41^{\circ} \mathrm{C}$ odnosno na $43^{\circ} \mathrm{C}$. U jogurtu obogaćenom s PWP broj živih stanica laktobacila bio je $5,2 \times 10^{9} \mathrm{CFU} \cdot \mathrm{mL}^{-1}$, dok se broj streptokokoka nakon 21 dan smanjio. Dodatak PWP nije utjecao na broj bifidobakterija.

\section{Ključne riječi: jogurt, polimerizirani proteini sirutke, antioksidacijska aktivnost, bakterije mliječne kiseline}

\section{References}

1. Amatayakul, T., Halmos, A.L, Sherkat, F., Shah, N.P. (2006): Physical characteristics of yoghurts made using exopolysaccharide-producing starter cultures and varying casein to whey protein ratios. International Dairy Journal 16, 40-51. https://doi.org/10.1016/j.idairyj.2005.01.004

2. Aloğlu, H.Ş., Öner, Z. (2011): Determination of antioxidant activity of bioactive peptide fractions obtained from yoghurt. Journal of Dairy Science 94, 5305-5314. https://doi.org/10.3168/jds.2011-4285

3. Benzie, I.F.F., Strain, J.J. (1996): The ferric reducing ability of plasma (FRAO) as a measure of 'antioxidant power': The FRAP assay. Analytical Biochemistry 239, 70-76. https://doi.org/10.1006/abio.1996.0292

4. Cruz, A.G., Cadena, R.S, Faria, J.A., Bolini, H.M., Dantas, C., Ferreira, M.M., Deliza, R. (2012): PARAFAC: Adjustment for modeling consumer study covering probiotic and conventional yoghurt. Food Research International 45, 211-215. https://doi.org/10.1016/j.foodres.2011.09.031
5. Giordano, S., Darley-Usmar, V., Zhang, J. (2014): Autophagy as an essential cellular antioxidant pathway in neurodegenerative disease. Redox Biology 2, 82-90. https://doi.org/10.1016/j.redox.2013.12.013

6. Gjorgievski, N., Tomovska, J., Dimitrovska, G., Makarijoski, B., Shariati, M.A. (2014): Determination of the antioxidant activity in yoghurt. Journal of Hygienic Engineering and Design 8, 88-92.

7. Granato, D., Branco, G.F., Nazzaro, F., Cruz, A.G., Faria, J.A. (2010): Functional foods and nondairy probiotic food development: trends, concepts, and products. Comprehensive Reviews in Food Science and Food Safety 9 , 292-302. https://doi.org/10.1111/j.1541-4337.2010.00110.x

8. Guessas, B., Adjoudj, F., Hadadji, M., Kihal, M. (2012): Isolation and identification of lactic acid bacteria from Dhan, a traditional butter and their major technological traits. World Applied Sciences Journal 17, 480-488. 
9. Gustaw, W. (2007): Effect of addition of whey protein aggregates obtained by single and double heating method on the rheological properties of set yoghurts. Polish Journal of Food and Nutrition Sciences 57 (A), 33-36.

10. Gustaw, W., Kozioł, J., Radzki, W., Skrzypczak, K., Michalak-Majewska, M., Sołowiej, B., Jabłońska-Ryś, E. (2016): The effect of addition of selected milk protein preparations on the growth of Lactobacillus acidophilus and physicochemical properties of fermented milk. Acta Scientiarum Polonorum Technologia Alimentaria 15, 29-36. http://dx.doi.org/10.17306/J.AFS.2016.1.3

11. Hwang, H.S., Winkler-Moser, J.K. (2017): Antioxidant activity of amino acids in soybean oil at frying temperature: Structural effects and synergism with tocopherols. Food Chemistry 221, 1168-1177. https://doi.org/10.1016/j.foodchem.2016.11.042

12. Illupapalayam, V.V., Smith, S.C., Gamlath, S. (2014): Consumer acceptability and antioxidant potential of probiotic-yoghurt with spices. LWT-Food Science and Technology 55, 255-262. https://doi.org/10.1016/j.lwt.2013.09.025

13. Kristo, E., Biliaderis, C.G., Tzanetakis, N. (2003): Modelling of rheological, microbiological and acidification properties of a fermented milk product containing a probiotic strain of Lactobacillus paracasei. International Dairy Journal 13 , 517-528. https://doi.org/10.1016/S0958-6946(03)00074-8

14. Lammert, A., Olabi, A., Kalache, L., Brooks, K., Tong, P. (2014): Characterisation of the sensory properties of whey protein concentrates. International Journal of Dairy Technology 67, 135-141. https://doi.org/10.1111/1471-0307.12102

15. Madureira, A.R., Tavares, T., Gomes, A.M.P., Pintado, M.E., Malcata, F.X. (2010): Invited review: physiological properties of bioactive peptides obtained from whey proteins. Journal of Dairy Science 93, 437-455. https://doi.org/10.3168/jds.2009-2566

16. Mainville, I., Montpetit, D., Durand, N., Farnworth, E.R. (2001): Deactivating the bacteria and yeast in kefir using heat treatment, irradiation and high pressure. International Dairy Journal 11, 45-49. https://doi.org/10.1016/S0958-6946(01)00038-3

17. Peńa-Ramos, E.A., Xiong, Y.L. (2001): Antioxidative activity of whey protein hydrolysates in a liposomal system. Journal of Dairy Science 84, 2577-2583. https://doi.org/10.3168/jds.S0022-0302(01)74711-X
18. Pownall, T.L, Udenigwe, C.C., Aluko, R.E. (2010): Amino acid composition andantioxidant properties of pea seed (Pisum sativum L.) enzymatic proteinhydrolysate fractions. Journal of Agricultural and Food Chemistry 58, 4712-4718. https://doi.org/10.1016/j.cca.2014.06.004

19. Rajendran, P., Nandakumar, N., Rengarajan, T., Palaniswami, R., Gnanadhas, E.N., Lakshminarasaiah, U., Nishigaki, I. (2014): Antioxidants and human diseases. Clinica Chimica Acta 436, 332-347. https://doi.org/10.1016/j.cca.2014.06.004

20. Sah, B.N.P., Vasiljevic, T., McKechnie, S., Donkor, O.N. (2014): Effect of probiotics on antioxidant and antimutagenic activities of crude peptide extract from yoghurt. Food Chemistry 156, 264-270. https://doi.org/10.1016/j.foodchem.2014.01.105

21. Sánchez-Moreno, C., Larrauri, J.A., Saura-Calixto, F.A. (1998): Procedure to measure the antiradical efficiency of polyphenols. Journal of the Science of Food and Agriculture 76, 270-276.

https://doi.org/10.1002/(SICI)10970010(199802)76:2<270::AID-JSFA945>3.0.CO;2-9

22. Smithers, G.W. (2008): Whey and whey proteins-from 'gutter-to-gold'. International Dairy Journal 18, 695-704. https://doi.org/10.1016/j.idairyj.2008.03.008

23. Svanborg, S., Johansen, A.G., Abrahamsen, R.K., Skeie, S.B. (2015): The composition and functional properties of whey protein concentrates produced from buttermilk are comparable with those of whey protein concentrates produced from skimmed milk. Journal of Dairy Science 98, 5829-5840. http://dx.doi.org/10.3168/jds.2014-9039

24. Wang, W., Bao, Y., Hendricks, G.M., Guo, M. (2012): Consistency, microstructure and probiotic survivability of goat's milk yoghurt using polymerized whey protein as a co-thickening agent. International Dairy Journal 24, 113119. https://doi.org/10.1016/j.idairyj.2011.09.007

25. Xue, Z., Yu, W., Liu, Z., Wu, M., Kou, X., Wang, J. (2009): Preparation and antioxidative properties of a rapeseed (Brassica napus) protein hydrolysate and three peptide fractions. Journal of Agricultural and Food Chemistry 57, 5287-5293.

https://doi.org/10.1021/jf900860v 